\title{
PERAN KECERDASAN EMOSIONAL DAN KOMITMEN ORGANISASI DALAM KINERJA KARYAWAN PT. COGINDO DAYA BERSAMA UNIT SURALAYA
}

\author{
Nafiudin $^{(1)}$ \\ Nafiuddin08@gmail.com
}

$\operatorname{Karman}^{(2)}$

Program Studi Manajemen Fakultas Ekonomi dan Bisnis Universitas Serang Raya

\begin{abstract}
ABSTRAK
Tujuan dari penelitian ini adalah untuk menganalisis pengaruh kecerdasan emosional dan komitmen organisasi terhadap kinerja karyawan PT. Cogindo DayaBersama dan untuk menganalisis variabel yang lebih dominan berpengaruh dalam meningkatkan kinerja pegawai pada PT. Cogindo Daya Bersama.

Metode yang digunakan dalam penelitian ini yaitu dari mulai penarikan populasi sebanyak 128 dan sampel dengan menggunakan slovin dengan total responden 97 hingga pengumpulan data baik itu data primer maupun data sekunder. Pengujian dilakukaan dengan berbagai instrument diantarnya dengan uji validitas dan uji reliabilitas data setelah itu dilakukan analisisi data dengan analisis asosiatif dan pengujian hipotesis.

Berdasarkan hasil analisis data yang digunakan diketahui bahwa nilai koefisien determinasi atau nilai Rsquere yang dihasilkan yaitu sebesar 0,415 artinya pengaruh Kecerdasan Emosional dan Komitmen Organisasi Terhadap Kinerja Karyawan adalah 41\% sisanya 59\% dipengaruhi oleh faktor lain yang tidak dibahas dalam penelitian ini.
\end{abstract}

Kata Kunci : Kecerdasan Emosional, Komitmen Organisasi, Kinerja Karyawan

\section{ABSTRACT}

The purpose of this study was to analyze the influence of emotional intelligence and organizational commitment to the performance of employees of PT. Cogindo DayaBersama and to analyze the more dominant variable influential in improving employee performance at PT. Cogindo DayaBersama.

The method used in this research is from the start of population withdrawal as much as 128 and sample by using slovin with total of 97 respondents to collecting data either primary data or secondary data. Tests dilakukaan with various instruments diantarnya with validity test and data reliability test after that done data analysis with associative analysis and hypothesis testing.

Based on the results of data analysis used is known that the value of coefficient of determination or value of Rsquere generated that is equal to 0.415 means the influence of Emotional Intelligence and Organizational Commitment to Employee Performance is $41 \%$ the remaining $59 \%$ influenced by other factors not discussed in this study.

Keywords: Emotional Intelligence, Organizational Commitment, Employee Performance 


\section{PENDAHULUAN}

Sumber daya manusia merupakan faktor kunci bagi kemajuan dan perkembangan organisasi oleh karena sumberdaya manusia harus diperhatikan sebagai sumber intelektualitas dalam sebuah organisasi yang sewaktu-waktu bisa berpindah ke organisasi lain yang lebih memperhatikan sumber daya manusia dan umumnya sebagian besar organisasi yang ada percaya bahwa untuk mencapai sebuah keberhasilan, harus mengupayakan kinerja individu semaksimal mungkin, karena pada dasarnya kinerja individu akan sangat berpengaruh terhadap kinerja baik kinerja tim maupun kelompok.

Salah satu faktor yang dianggap penting bagi peningkatan kinerja karyawan yaitu kecerdasan emosional (EQ) yang merupakan sisi lain dari kecerdasan yang dimiliki manusia yang dianggap berperan penting dalam menentukan tingkat kesuksesan hidup.

Faktor lain yang mempengaruhi kinerja karyawan adalah komitmen organisasi karyawan pada perusahaan yang dapat dijadikan salah satu jaminan untuk menjaga kelangsungan perusahaan. Komitmen organisasi karyawan menjadi hal yang penting bagi sebuah organisasi dalam menciptakan kelangsungan hidup sebuah organisasi apapun bentuk organisasinya.

Peningkatan kinerja harus didukung dengan pengelolaan kecerdasan emosional dan memiliki komitmen organisasi yang baik sehingga dapat memberikan dorongan atau gairah kerja baru bagi karyawan terutama pada karyawan PT. Cogindo DayaBersama unit suralaya.

Kecerdasan emosional merupakan kemampuan emosi yang meliputi kemampuan untuk mengendalikan diri, memiliki daya tahan ketika menghadapi suatu masalah, mampu mengendalikan impuls, memotivasi diri, mampu mengatur suasana hati, kemampuan berempati dan membina hubungan dengan orang lain" Kecerdasan emosi dapat menempatkan emosi seseorang pada porsi yang tepat, memilah kepuasan dan mengatur suasana hati. Goleman (2009:45)

Definisi lain tentang kecerdasan emosi adalah suatu kecerdasan sosial yang berkaitan dengan kemampuan individu dalam memantau baik emosi dirinya maupun emosi orang lain, dan juga kemampuannya dalam membedakan emosi dirinya dengan emosi orang lain, dimana kemampuan ini digunakan untuk mengarahkan pola pikir dan perilakunya". Mayer dan Salovey (Makmun Mubayidh 2006:15)

Berdasarkan dua definisi di atas maka dapat disimpukan bahwa kecerdasan emosional merupakan kemampuan seseorang dalam mengelola keadaan emosinya secara proporsional sehingga mampu memotivasi individu terebut dalam bekerja.

Kecerdasan emosional sangat dipengaruhi oleh beberapa faktor, baik faktor Psikologis maupun pelatihan emosi. Faktor psikologi Faktor ini akan membantu individu dalam mengelola, mengontrol, mengendalikan dan mengkoordinasikan keadaan emosi agar termanifestasi dalam perilaku secara efektif sedangkan faktor pelatihan emosi Kegiatan yang dilakukan secara berulang-ulang akan menciptakan kebiasaan, dan kebiasaan rutin tersebut akan menghasilkan pengalaman yang berujung pada pembentukan nilai (value). 
Komitmen adalah sikap kesediaan diri untuk memegang teguh visi, misi serta kemauan untuk mengerahkan seluruh usaha dalam melaksanakan tugas. Komitmen karyawan tidak akan tumbuh dengan sendirinya, ada hubungan signifikan antara budaya kerja dengan komitmen karyawan Robin dan Judge (2007:284).

Menurut Anwar (2008:113), Komitmen Organisasi adalah seperangkat asumsi atau sistem keyakinan, nilai- nilai dan norma yang dikembangkan dalam organisasi yang dijadikan pedoman tingkah laku bagi anggota-anggotanya untuk mengatasi masalah adaptasi eksternal dan integrasi internal.

Sedangkan komitmen Menurut Robbins dan Judge (2008:100) komitmen adalah suatu keadaan di mana seorang karyawan memihak organisasi tertentu serta tujuan-tujuan dan keinginannya untuk mempertahankan keanggotaan dalam organisasi tersebut. Jadi, keterlibatan pekerjaan yang tinggi berarti memihak pada pekerjaan tertentu seorang individu, sementara komitmen organisasional yang tinggi berarti memihak organisasi yang merekrut individu tersebut.

Menurut Sopiah (2008:155), Komitmen organisasional adalah keinginan anggota organisasi untuk mempertahankan keanggotaannya dalam organisasi dan bersedia berusaha keras bagi pencapaian tujuan. Organisasi. Komitmen organisasional mencakup kebanggaan anggota, kesetiaan anggota, dan kemauan anggota pada organisasi.

Kesimpulan dari beberapa definisi di atas bahwa komitmen oraganisasi merupakan sikap seseorang yang tercermin dalam tindakannya seperti bekerja keras untuk organisasi, memegang teguh pada norma-norma perusahaan untuk mencapai tujuan perusahaan. Komitmen organisasi mempunyai peranan dan pengaruh dalam kegiatan organisasi, baik itu pekerjaan maupun kecerdasan emosional dalam bekerja komitmen organisasi merupakan semangat karyawan dalam bekerja dan menghabiskan waktu sepanjang hari, tentu saja ini akan sangat berpengaruh kepada kinerja karyawan. Masalah yang harus dihadapi seperti suasana dan kondisi kerja dan hubungan karyawan. Komitmen organisasi kadang menjadi faktor penentu tujuan dan target kinerja karyawan, dimana karyawan banyak menghabiskan waktu sehari hari

Berdasarkan survey pendahuluan di lokasi penelitian dapat dilihat dari kurangnya kinerja pegawai dalam melaksakan tugas - tugasnya dan tanggungjawab sehingga kinerja pegawai menurun, seperti halnya bahwa hasil kerja terelasisasi sebesar $75 \%$ dan kurang dari target yan telah ditentukan perusahaan yaitu 100\%, masih terdapat karyawan yang belum menyadari akan pentingnya meningkatkan kinerja sehingga mengakibatkan kualitas kerja menurun.

Berdasarkan latar belakang diatas, maka penelitian ini merumuskan masalah sebagai berikut:

1. Apakah pengaruh kecerdasan emosional berpengaruh terhadap kinerja karyawan pada PT. Cogindo Daya Bersama unit suralaya.

2. Apakah pengaruh komitmen organisasi berpengaruh terhadap kinerja karyawan Pada PT. Cogindo Daya Bersama unit suralaya. 
3. Apakah pengaruh kecerdasan emosional dan komitmen organisasi berpengaruh terhadap kinerja karyawan Pada PT. Cogindo Daya Bersama unit suralaya.

Dalam kaitannya dengan uraian tersebut di atas maka dapat disajikan kerangka pikir yang digunakan dalam penelitian ini yang dapat digambarkan sebagai berikut

\section{Gambar Kerangka Berfikir}

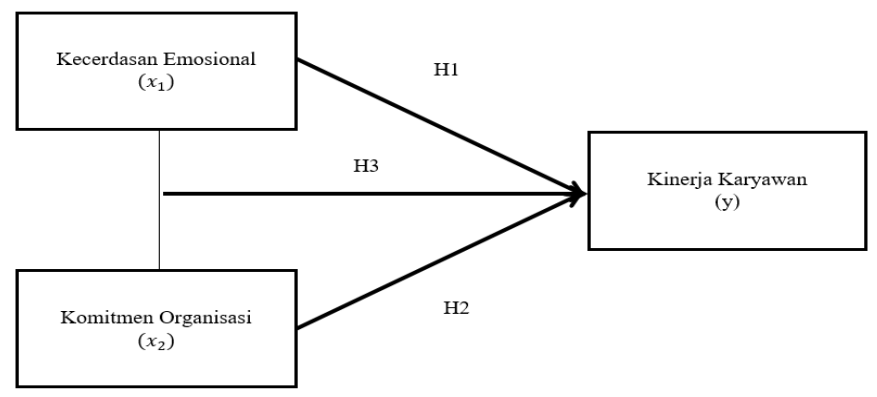

Dari masalah pokok yang telah dikemukakan di atas, berikut ini dapat disajikan hipotesis sebagai jawaban atau dugaan sementara dalam penelitian ini, yaitu sebagai berikut :

1. Kecerdasan emosional berpengaruh secara signifikan terhadap kinerja karyawan pada PT. Cogindo DayaBersama.

2. Komitmen Organisasi berpengaruh secara signifikan terhadap kinerja karyawan pada PT. Cogindo DayaBersama.

3. Terdapat pengaruh signifikan antara kecerdasan emosional dan komitmen organisasi terhadap kinerja karyawan pada PT. Cogindo DayaBersama

\section{METODE PENELITIAN}

Penulis mengunakan metode deskriptif dan metode asosiatif. Metode deskriptif adalah penelitian yang bertujuan untuk menggambarkan sifat sesuatu yang tengah berlangsung pada saat riset dilakukan dan memeriksa sebab-sebab dari suatu gejala tertentu. Sedangkan metode asosiatif merupakan penelitian yang bertujuan untuk mengetahui hubungan antara dua variabel atau lebih, sugiyono (2005:1).

\section{Jenis dan Sumber Data}

Adapun jenis data yang diperoleh dari penelitian ini adalah bersumber dari data kuantitatif yaitu data atau informasi yang dapat dihitung misalnya jumlah pegawai, serta data lainnya yang dapat menunjang pokok pembahasan skripsi ini. Sedangkan data yang diperoleh bersumber dari:

1. Data primer yaitu data mengenai obyek penelitian yang diperoleh melalui hasil penyebaran kuesioner yang disebarkan kepada sejumlah pegawai pada PT. Cogindo Daya Bersama Unit Suralaya.

2. Data sekunder yaitu data yang diperoleh secara tertulis berupa dokumen-dokumen PT. Cogindo Daya Bersama Unit Suralaya. yang ada kaitannya dengan masalah yang akan di bahas. 


\section{Populasi dan Sampel}

1. Populasi adalah wilayah generalisasi yang terdiri dari objek atau subjek yang memiliki kuantitas dan karakteristik tertentu yang diterapkan oleh peneliti untuk dipelajari kemudian ditarik kesimpulannya (sugiyono, 2010:80). Populasi dalam penelitian ini seluruh pegawai PT. Cogindo Daya Bersama Unit Suralaya sejumlah 128 Pegawai.

2. Sampel adalah bagian dari jumlah dan krakteristik yang dimiliki oleh populasi tersebut dan sampel yang diambil dari populasi harus betul - betul reprentetative (mewakili) (sugiyono, 2010:81).

Teknik yang digunakan oleh penulis adalah teknik Simple Random Sampling. Dikatakan simple (sederhana) karena pengambilan sampel dari populasi dilakukan secara acak tanpa memperhatikan strata yang ada dalam populasi itu.Sapel dihitung berdasarkan rumus solvin maka untuk menentukan sampel digunakan rumus slovin,

Sedangkan dalam menjawab hipotesis dalam pnelitian ini penulis menggunakan beberapa alat uji yaitu Analisis Regresi liner berganda, Uji Asumsi Klasik, Uji Keabsahan data dan Uji t dan Uji F.

\section{HASIL DAN PEMBAHASAN}

\section{Uji Validitas}

Uji validitas digunakan untuk menunjukkan tingkat kevalidan instrumen penelitian, artinya instrumen dapat digunakan untuk mengukur apa yang seharusnya diukur. Untuk menentukan hasil dari tiap butir instrument variable Kecerdasan Emosional, Komiotmen Organisas dan Kinerja Karyawan penulis menggunakan rumus koefisiensi korelasi product moment, dengan membanding $\mathrm{r}_{\text {hitung }}$ dan $\mathrm{r}_{\text {tabel }}$ nilai untuk 97 responden dengan signifikan $5 \%$ yaitu $(n-2)=95$ yaitu diperoleh $r_{\text {tabel }} 0,202$ Hasil pengujian validitas masing-masing variable menggunakan SPSS Versi 20 dengan melihat nilai Corrected item-total Correlation, dan hasilnya adalah sebagai berikut:

Hasil Output Spss Uji Validitas Variabel Kecerdasan Emosional $\left(\mathbf{X}_{1}\right)$

\begin{tabular}{|c|c|c|c|c|c|c|c|c|c|c|}
\hline & & $\overline{K E .1}$ & KE. 2 & KE. 3 & KE 4 & KE. 5 & KE. 6 & KE. 7 & KE. 8 & TOTAL \\
\hline \multirow{4}{*}{ KE. 1} & Pearson & 1 & $621^{m}$ & $725^{\circ}$ & $386^{-}$ & $581^{m}$ & $622^{m}$ & $646^{-1}$ & $588^{-1}$ & $789^{-1}$ \\
\hline & Sig. (2-tailed) & & ,ooo & ,ooo & .035 & .001 & ,ooo & ,ooo & .001 & .000 \\
\hline & & 30 & 30 & зо & 30 & 30 & 30 & & зо & \\
\hline & $\begin{array}{l}\text { Pearson } \\
\text { Correlation }\end{array}$ & $.621^{-}$ & 1 & $.759^{\circ}$ & $.549^{--}$ & ,619" & $.732^{-1}$ & $683^{-\infty}$ & $.540^{-1}$ & $840^{\circ}$ \\
\hline KE. 2 & Sig. (2-tailed) & $\begin{array}{r}.000 \\
30\end{array}$ & зо & $\begin{array}{r}, 000 \\
30\end{array}$ & $\begin{array}{r}002 \\
30\end{array}$ & $\begin{array}{r}, 000 \\
30\end{array}$ & $\begin{array}{r}.000 \\
30\end{array}$ & $\begin{array}{r}\text {, } \\
\text { 30о }\end{array}$ & $\begin{array}{r}002 \\
30\end{array}$ & , 000 \\
\hline \multirow{2}{*}{ KE.3 } & $\begin{array}{l}\text { Pearson } \\
\text { Correlation }\end{array}$ & $.725^{-1}$ & $.759^{\circ-}$ & 1 & $.517^{-}$ & $.725^{\circ}$ & .672 & $.624^{-1}$ & $628^{-1}$ & $.867^{\circ}$ \\
\hline & Sig. (2-tailed) & $\begin{array}{r}.000 \\
30\end{array}$ & , 000 & 30 & $\begin{array}{r}003 \\
30\end{array}$ & $\begin{array}{r}.000 \\
30\end{array}$ & , & $\begin{array}{r}.000 \\
30\end{array}$ & ,000 & .000 \\
\hline \multirow[b]{2}{*}{ KE. 4} & $\begin{array}{l}\text { Pearson } \\
\text { Correlation }\end{array}$ & $.386^{-}$ & $.549^{-\infty}$ & $.517^{\mu}$ & 1 & $.530^{--}$ & $618^{-}$ & $.518^{-1}$ & $683^{-}$ & $.749^{-}$ \\
\hline & Sig. (2-tailed) & $\begin{array}{r}.035 \\
30\end{array}$ &, 002 & $\begin{array}{r}.003 \\
30\end{array}$ & 30 & $\begin{array}{r}.003 \\
30\end{array}$ & $\begin{array}{r}.000 \\
30\end{array}$ & $\begin{array}{r}, 003 \\
30\end{array}$ & $\begin{array}{r}000 \\
30\end{array}$ & .000 \\
\hline \multirow{2}{*}{ KE. 5} & $\begin{array}{l}\text { Pearson } \\
\text { Correlation }\end{array}$ & $.581^{-}$ & $619^{-\infty}$ & $.725^{-1}$ & $.530^{-1}$ & 1 & $.538^{-}$ & $.557^{-}$ & $.599^{-1}$ & $786^{-1}$ \\
\hline & $\begin{array}{l}\text { Sig. (2-tailed) } \\
\text { N }\end{array}$ & $\begin{array}{r}.001 \\
30\end{array}$ & $\begin{array}{r}\text {, } \\
300\end{array}$ & $\begin{array}{r}000 \\
30\end{array}$ & $\begin{array}{r}, 003 \\
30\end{array}$ & & $\begin{array}{r}002 \\
30\end{array}$ & $\begin{array}{r}001 \\
30\end{array}$ & $\begin{array}{r}.000 \\
30\end{array}$ & $\begin{array}{r}.000 \\
30\end{array}$ \\
\hline \multirow{2}{*}{ KE. 6} & $\begin{array}{l}\text { Pearson } \\
\text { Correlation }\end{array}$ & $.622^{--}$ & $.732^{-1}$ & $.672^{--}$ & $.618^{-1}$ & $.538^{-1}$ & 1 & $.734^{-1}$ & $.545^{-1}$ & $840^{-1}$ \\
\hline & $\begin{array}{l}\text { Sig. (2-tailed) } \\
\mathrm{N}\end{array}$ & $\begin{array}{r}.000 \\
30\end{array}$ & $\begin{array}{r}.000 \\
30\end{array}$ & $\begin{array}{r}, 000 \\
30\end{array}$ & $\begin{array}{r}.000 \\
30\end{array}$ & $\begin{array}{r}002 \\
30\end{array}$ & зо & $\begin{array}{r}000 \\
30\end{array}$ & $\begin{array}{r}002 \\
30\end{array}$ & $\begin{array}{r}.000 \\
30\end{array}$ \\
\hline \multirow[b]{2}{*}{ KE.7 } & $\begin{array}{l}\text { Pearson } \\
\text { Correlation }\end{array}$ & $.646^{-1}$ & $.683^{-}$ & $.624^{-1}$ & $.518^{-}$ & $.557^{-}$ & $.734^{-\infty}$ & 1 & $.575^{-1}$ & $821^{-1}$ \\
\hline & Sig. (2-tailed) & $\begin{array}{r}, 000 \\
30\end{array}$ & , & ,000 & ,003 & $\begin{array}{r}001 \\
30\end{array}$ & $\begin{array}{r}.000 \\
30\end{array}$ & зо & $\begin{array}{r}001 \\
30\end{array}$ &, 000 \\
\hline \multirow{3}{*}{ KE. 8} & $\begin{array}{l}\text { Pearson } \\
\text { Correlation }\end{array}$ & $.588^{--}$ & $.540^{-\infty}$ & $.628^{-\infty}$ & $.683^{-}$ & $.599^{-\infty}$ & $.545^{-\infty}$ & $.575^{-1}$ & 1 & $.804^{-1}$ \\
\hline & Sig. (2-tailed) & $\begin{array}{r}001 \\
30\end{array}$ &, 002 & ,000 & $\begin{array}{r}, 000 \\
30\end{array}$ & $\begin{array}{r}, 000 \\
30\end{array}$ &, 002 & $\begin{array}{r}001 \\
30\end{array}$ & зо & .000 \\
\hline & $\begin{array}{l}\text { Pearson } \\
\text { Correlation }\end{array}$ & .789 & $840^{-}$ & $.867^{-\infty}$ & $.749^{-}$ & $.786^{\circ}$ & $840^{--}$ & $821^{-}$ & $804^{-\infty}$ & 1 \\
\hline TOTAL & Sig. (2-tailed) & ., 000 & ,ooo & .000 & ,ooo & ,ooo & .000 & .000 & .000 & \\
\hline & $\mathrm{N}$ & 30 & 30 & 30 & 30 & 30 & 30 & 30 & 30 & 30 \\
\hline
\end{tabular}


Hasil Output Spss Uji Validitas Variabel Komitmen Organisasi $\left(\mathbf{X}_{2}\right)$

\begin{tabular}{|c|c|c|c|c|c|c|c|c|}
\hline \multicolumn{9}{|c|}{ Correlations } \\
\hline & & & $\mathrm{nU} .2$ & nU.s & $\mathrm{KO} .4$ & KU.5 & KO. & 10IAL \\
\hline \multirow{4}{*}{$\mathrm{KO} .1$} & Pearson Correlation & 1 &, $732^{* *}$ &, $586^{* *}$ & $.464^{* *}$ &, 112 &, 346 & $839^{k=}$ \\
\hline & Sig. (2-tailed) & &, 000 &, 001 &, 010 &, 556 &, 061 &, 000 \\
\hline & $\mathrm{N}$ & 30 & 30 & 30 & 30 & 30 & 30 & 30 \\
\hline & Pearson Correlation &, $732^{* *}$ & 1 &, $661^{* *}$ &, $365^{*}$ &, $448^{*}$ &, 229 & $858^{* *}$ \\
\hline \multirow[t]{3}{*}{$\mathrm{KO} .2$} & Sig. (2-tailed) &, 000 & &, 000 &, 047 &, 013 &, 223 &, 000 \\
\hline & $\mathrm{N}$ & 30 & 30 & 30 & 30 & 30 & 30 & 30 \\
\hline & Pearson Correlation &, $586^{\star *}$ &, $661^{\star *}$ & 1 &, 315 &, $416^{*}$ &, 261 &, $788^{* *}$ \\
\hline \multirow[t]{3}{*}{$\mathrm{KO} .3$} & Sig. (2-tailed) & ,001 &, 000 & &, 090 &, 022 & 163 &, 000 \\
\hline & $\mathrm{N}$ & 30 & 30 & 30 & 30 & 30 & 30 & 30 \\
\hline & Pearson Correlation & $464^{\star *}$ &, $365^{*}$ &, 315 & 1 &, 109 &, 058 &, $582^{* *}$ \\
\hline \multirow[t]{3}{*}{$\mathrm{KO} .4$} & Sig. (2-tailed) & 010 & 047 & 090 & &, 567 & 761 &, 001 \\
\hline & $\mathrm{N}$ & 30 & 30 & 30 & 30 & 30 & 30 & 30 \\
\hline & Pearson Correlation &, 112 & $448^{*}$ &, $416^{*}$ &, 109 & 1 &, 166 &, $502^{* *}$ \\
\hline \multirow[t]{3}{*}{ KO. 5} & Sig. (2-tailed) & 556 & 013 &, 022 & 567 & & 382 &, 005 \\
\hline & $\mathrm{N}$ & 30 & 30 & 30 & 30 & 30 & 30 & 30 \\
\hline & Pearson Correlation &, 346 & ,229 &, 261 &, 058 &, 166 & 1 &, $485^{* *}$ \\
\hline \multirow[t]{3}{*}{ KO. 6} & Sig. (2-tailed) & 061 &, 223 & 163 &, 761 & ,382 & &, 007 \\
\hline & $\mathrm{N}$ & 30 & 30 & 30 & 30 & 30 & 30 & 30 \\
\hline & Pearson Correlation & $839^{* *}$ & $858^{* *}$ &, $788^{* *}$ &, $582^{* *}$ &, $502^{* *}$ & $485^{\star *}$ & 1 \\
\hline \multirow[t]{2}{*}{ TOTAL } & Sig. (2-tailed) &, 000 &, 000 &, 000 &, 001 &, 005 &, 007 & \\
\hline & $\mathrm{N}$ & 30 & 30 & 30 & 30 & 30 & 30 & 30 \\
\hline
\end{tabular}

Hasil Output Spss Uji Validitas Variabel Kinerja Karyawan (Y)

Correlations

\begin{tabular}{|c|c|c|c|c|c|c|c|c|c|}
\hline & & KE.1 & KE. 2 & KE.3 & KE.4 & KE.5 & KE.6 & KE.7 & TOTAL \\
\hline \multirow{3}{*}{ KE. 1} & $\begin{array}{l}\text { Pearson } \\
\text { Correlation }\end{array}$ & 1 &, $744^{* *}$ & $.509^{* *}$ & $=494^{* *}$ & $.585^{* *}$ & $=486^{* *}$ & $.725^{* *}$ & $.756^{* *}$ \\
\hline & Sig. (2-tailed) & & .000 &, 004 &, 006 &, 001 &, 007 & .000 &, 000 \\
\hline & $\mathrm{N}$ & 30 & 30 & 30 & 30 & 30 & 30 & 30 & 30 \\
\hline \multirow{3}{*}{ KE. 2} & $\begin{array}{l}\text { Pearson } \\
\text { Correlation }\end{array}$ &, $744^{* *}$ & 1 & $.555^{* *}$ &, $762^{* *}$ & $.578^{* *}$ & $=672^{* *}$ & $965^{* *}$ & $896^{* *}$ \\
\hline & Sig. (2-tailed) & .000 & & .001 &, 000 &, 001 &, 000 &, 000 &, 000 \\
\hline & N & 30 & 30 & 30 & 30 & 30 & 30 & 30 & 30 \\
\hline \multirow{2}{*}{ KE. 3} & $\begin{array}{l}\text { Pearson } \\
\text { Correlation }\end{array}$ &, $509^{* *}$ & $.555^{* *}$ & 1 & $.565^{* *}$ &, $664^{* *}$ & $=789^{* *}$ & $601^{* *}$ & $811^{* *}$ \\
\hline & $\begin{array}{l}\text { Sig. (2-tailed) } \\
\mathrm{N}\end{array}$ & $\begin{array}{r}.004 \\
30\end{array}$ & $\begin{array}{r}001 \\
30\end{array}$ & 30 & $\begin{array}{r}001 \\
30\end{array}$ & $\begin{array}{r}.000 \\
30\end{array}$ & $\begin{array}{r}.000 \\
30\end{array}$ & $\begin{array}{r}.000 \\
30\end{array}$ & $\begin{array}{r}.000 \\
30\end{array}$ \\
\hline \multirow{2}{*}{ KE. 4} & $\begin{array}{l}\text { Pearson } \\
\text { Correlation }\end{array}$ &, $494^{* *}$ & $.762^{* *}$ & $.565^{* *}$ & 1 &, $645^{* *}$ &, $666^{* *}$ &, $738^{* *}$ & $839^{* *}$ \\
\hline & $\begin{array}{l}\text { Sig. (2-tailed) } \\
\mathrm{N}\end{array}$ & $\begin{array}{r}.006 \\
30\end{array}$ & $\begin{array}{r}.000 \\
30\end{array}$ & $\begin{array}{r}.001 \\
30\end{array}$ & 30 & $\begin{array}{r}000 \\
30\end{array}$ & $\begin{array}{r}, 000 \\
30\end{array}$ & $\begin{array}{r}000 \\
30\end{array}$ & $\begin{array}{r}.000 \\
30\end{array}$ \\
\hline \multirow{3}{*}{ KE. 5} & $\begin{array}{l}\text { Pearson } \\
\text { Correlation }\end{array}$ & $.585^{* *}$ & $.578^{* *}$ & $.664^{* *}$ & $.645^{* *}$ & 1 &, $570^{* *}$ &, $568^{* *}$ & $.789^{* *}$ \\
\hline & Sig. (2-tailed) & .001 & .001 &, 000 & .000 & &, 001 & .001 &, 000 \\
\hline & $\mathrm{N}$ & 30 & 30 & 30 & 30 & 30 & 30 & 30 & 30 \\
\hline \multirow{3}{*}{ KE. 6} & $\begin{array}{l}\text { Pearson } \\
\text { Correlation }\end{array}$ &, $486^{* *}$ & $.672^{* *}$ & $.789^{* *}$ & $.666^{* *}$ & $.570^{* *}$ & 1 & $.714^{* *}$ & $850^{* *}$ \\
\hline & Sig. (2-tailed) & .007 & .000 &, 000 & .000 &, 001 & & .000 & .000 \\
\hline & $\mathrm{N}$ & 30 & 30 & 30 & 30 & 30 & 30 & 30 & 30 \\
\hline \multirow{2}{*}{ KE. 7} & $\begin{array}{l}\text { Pearson } \\
\text { Correlation }\end{array}$ &, $725^{* *}$ & $965^{* *}$ & $.601^{* *}$ &, $738^{* *}$ &, $568^{* *}$ &, $714^{* *}$ & 1 & $903^{* *}$ \\
\hline & $\begin{array}{l}\text { Sig. (2-tailed) } \\
\mathrm{N}\end{array}$ & $\begin{array}{r}.000 \\
30\end{array}$ & $\begin{array}{r}.000 \\
30\end{array}$ & $\begin{array}{r}.000 \\
30\end{array}$ & $\begin{array}{r}.000 \\
30\end{array}$ & $\begin{array}{r}001 \\
30\end{array}$ & $\begin{array}{r}000 \\
30\end{array}$ & 30 & $\begin{array}{r}000 \\
30\end{array}$ \\
\hline \multirow{3}{*}{ TOTAL } & $\begin{array}{l}\text { Pearson } \\
\text { Correlation }\end{array}$ &, $756^{* *}$ & $896^{* *}$ & $811^{* *}$ & $839^{* *}$ &, $789^{* *}$ & $850^{* *}$ &, $903^{* *}$ & 1 \\
\hline & Sig. (2-tailed) & 000 &, 000 &, 000 & .000 &, 000 &, 000 & .000 & \\
\hline & $\mathrm{N}$ & 30 & 30 & 30 & 30 & 30 & 30 & 30 & 30 \\
\hline
\end{tabular}

\section{Uji Reliabilitas}

Uji reliabilitas digunakan untuk menunjukkan bahwa instrumen yang digunakan memiliki konsisten dalam hasil pengukuran. Adapun hasil output pengujian reliabilitas variabel Kecerdasan Emosional $\left(\mathrm{X}_{1}\right)$ menggunakan program SPSS Versi 20 adalah sebagai berikut:

\section{Hasil Output Spss Uji Reliabilitas Variabel Kecerdasan Emosional ( $\left.\mathbf{X}_{1}\right)$}




\begin{tabular}{|l|r|r|r|r|}
\hline & $\begin{array}{c}\text { Scale Mean if } \\
\text { Item Deleted }\end{array}$ & $\begin{array}{c}\text { Scale Variance } \\
\text { if Item Deleted }\end{array}$ & $\begin{array}{c}\text { Corrected Item- } \\
\text { Total } \\
\text { Correlation }\end{array}$ & $\begin{array}{c}\text { Cronbach's } \\
\text { Alpha if Item } \\
\text { Deleted }\end{array}$ \\
\hline KE1 & 26,3299 & 9,953 &, 535 &, 797 \\
KE2 & 26,2577 & 10,527 &, 559 &, 795 \\
KE3 & 26,3093 & 10,174 &, 551 &, 795 \\
KE4 & 26,2062 & 10,520 &, 452 &, 809 \\
KE5 & 26,4536 & 9,938 &, 582 &, 790 \\
KE6 & 26,2680 & 10,386 &, 516 &, 800 \\
KE7 & 26,4227 & 10,372 &, 547 &, 795 \\
KE8 & 26,2577 & 10,256 &, 554 &, 794 \\
\hline
\end{tabular}

\section{Hasil Output Spss Uji Reliabilitas Komitmen Organisasi $\left(\mathbf{X}_{2}\right)$}

\begin{tabular}{|l|r|r|r|r|}
\hline & $\begin{array}{c}\text { Scale Mean if } \\
\text { Item Deleted }\end{array}$ & $\begin{array}{c}\text { Scale Variance } \\
\text { if Item Deleted }\end{array}$ & $\begin{array}{c}\text { Corrected Item- } \\
\text { Total } \\
\text { Correlation }\end{array}$ & $\begin{array}{c}\text { Cronbach's } \\
\text { Alpha if Item } \\
\text { Deleted }\end{array}$ \\
\hline KO1 & 19,4433 & 7,666 &, 602 &, 807 \\
KO2 & 19,5773 & 7,705 &, 695 &, 790 \\
KO3 & 19,6289 & 7,152 &, 759 &, 773 \\
KO4 & 19,8351 & 8,139 &, 507 &, 826 \\
KO5 & 19,5567 & 7,645 &, 655 &, 796 \\
KO6 & 19,7423 & 8,422 &, 438 &, 839 \\
\hline
\end{tabular}

\section{Hasil Output Spss Uji Reliabilitas Variabel Kinerja Karyawan (Y)}

\begin{tabular}{|l|r|r|r|r|}
\hline & $\begin{array}{c}\text { Scale Mean if } \\
\text { Item Deleted }\end{array}$ & $\begin{array}{c}\text { Scale Variance } \\
\text { if Item Deleted }\end{array}$ & $\begin{array}{c}\text { Corrected Item- } \\
\text { Total } \\
\text { Correlation }\end{array}$ & $\begin{array}{c}\text { Cronbach's } \\
\text { Alpha if Item } \\
\text { Deleted }\end{array}$ \\
\hline KK1 & 24,7423 &, 483 &, 848 \\
KK2 & 24,6907 & 8,818 &, 662 &, 824 \\
KK3 & 24,5876 & 7,945 &, 612 &, 831 \\
KK4 & 24,5670 & 8,162 &, 722 &, 814 \\
KK5 & 24,5052 & 7,623 &, 625 \\
KK6 & 24,6907 & 8,148 &, 597 \\
KK7 & 24,5464 & 8,091 &, 533 \\
\hline
\end{tabular}

\section{Uji Normalitas}

Uji normalitas pada model regresi digunakan untuk menguji apakah nilai residual yang dihasilkan dari regresi terdistribusi secara normal atau tidak. Model regresi yang baik adalah yang memiliki nilai residual yang terdistribusi secara normal. Data yang baik dan layak untuk membuktikan model-model penelitian tersebut adalah data yang memiliki distribusi normal. Ada bermacam-macam cara untuk mendeteksi normalitas distribusi data, salah satunya menggunakan uji Kolmogorov-Smirnov. Hipotesis yang diajukan adalah sebagai berikut :

Ho : Data X berdistribusi normal

$\mathrm{Ha}$ : Data X tidak berdistribusi normal

Pengambilan keputusan : 
Jika Sig (p) > 0,05 maka Ho diterima

Jika Sig $(\mathrm{p})<0,05$ maka Ho ditolak

Dengan menggunakan alat bantu olah data program komputer SPSS versi 20 for windows didapati output sebagai berikut :

\section{Hasil Output Spss Uji Normalitas Data}

\begin{tabular}{|c|c|c|c|c|}
\hline & & $\begin{array}{c}\text { Kecerdasan } \\
\text { Emosional }\end{array}$ & $\begin{array}{l}\text { Komitmen } \\
\text { Organisasi }\end{array}$ & $\begin{array}{c}\text { Kinerja } \\
\text { Karyawan }\end{array}$ \\
\hline$N$ & & 97 & 97 & 97 \\
\hline \multirow{3}{*}{ Normal Parametersa,b } & Mean & 30,0722 & 23,5567 & 28,7216 \\
\hline & Std. Deviation & 3,61492 & 3,29447 & 3,28742 \\
\hline & Absolute & ,101 & ,111 & ,094 \\
\hline \multirow[t]{2}{*}{ Most Extreme Differences } & Positive & ,101 & ,078 & ,077 \\
\hline & Negative &,- 057 &,- 111 &,- 094 \\
\hline Kolmogorov-Smirnov Z & & ,996 & 1,094 & ,921 \\
\hline Asymp. Sig. (2-tailed) & &, 274 &, 183 &, 364 \\
\hline
\end{tabular}

Berdasarkan hasil output diketahui bahwa nilai Kolmogorov-Sirnev. sig. Variabel Kecerdasan Emosional adalah 0,274 dan nilai Kolmogorov-Sirnev. sig. Variabel Komitmen Organisasi adalah 0,183 yang berarti lebih dari 0,05 sehingga diputuskan bahwa Variabel Kecerdasan Emosional dan Komitmen Organiosasi memiliki distribusi data yang normal atau Ha diterima dan Ho ditolak.

\section{Uji Multikolonieritas}

Uji Multikolonieritas dimaksudkan untuk mengetahui ada tidaknya hubungan (korelasi) yang signifikan antar variabel bebas. Jika terdapat hubungan yang cukup tinggi (signifikan), berarti ada aspek yang sama diukur pada variabel bebas.

Uji multikolonieritas diolah dengan menggunakan program SPSS Versi 20 for windows dilakukan dengan uji regresi, dengan acuan niai VIF (variance inflation factor) dan koefisien korelasi antar variabel bebas. Dari pengolahan data tersebut dihasilkan ouput sebagi berikut.

\section{Hasil Output Spss Uji Multikolinieritas Data Coefficientsa}

\begin{tabular}{|c|c|c|}
\hline \multirow{2}{*}{ Model } & \multicolumn{2}{|c|}{ Collinearity Statistics } \\
\hline & Tolerance & VIF \\
\hline (Constant) & & \\
\hline Kecerdasan Emosional & ,958 & 1,044 \\
\hline Komitmen Organisasi & ,958 & 1,044 \\
\hline
\end{tabular}

a. Dependent Variable: Y

Dari hasil di atas dapat diketahui nilai variance inflation factor (VIF) kedua variabel yaitu $1,044<10$ dan Tolerance $958>100$, Artinya hubungan kuat antara variabel Kecerdasan Emosional (X1) dan Komitmen Organisasi (X2) Terhadap variabel Kinerja Kinerja Karyawan (Y). 


\section{Uji Heteroskedasitas}

\section{Hasil Output SPSS Untuk Uji Heteroskedasitas}

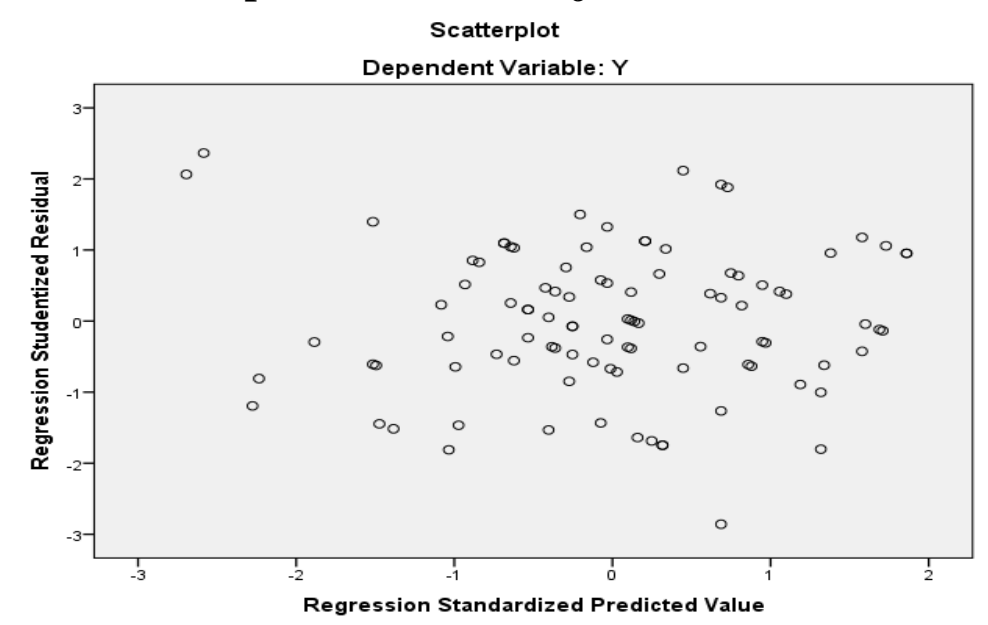

Dari gambar di atas maka dapat dipastikan bahwa tidak terjadi heteroskedasitas, karena tidak ada pola yang jelas, secara titik-titik menyebar diatas dan dibawah angka 0 pada sumbu Y.

\section{Uji Autokorelasi}

Uji autokorelasi bertujuan untuk melihat apakah terjadi korelasi antara variabel bebas terhadap variabel terikat, jadi tidak terdapat korelasi antara observasi dengan data observasi sebelumnya. Untuk mendeteksi ada tidaknya gejala autokorelasi dalam model regresi linier. pada penelitian ini penulis menggunakan metode Durbin - Watson (Uji DW) untuk uji autokorelasi dengan ketentuan sebagai berikut :

a. Jika d lebih kecil dari dL atau lebih besar dari (4-dL) maka Ho ditolak dan ha diterima, yang berarti terdapat autokorelasi

b. jika d terletak antara dU dan (4-dU), maka Ho diterima dan Ha ditolak, yang berarti tidak ada autokorelasi

c. jika d terletak antara dL dan dU atau diantara (4-dU) dan (4-dL), maka tidak menghasilkan kesimpulan yang pasti.

Dari hasil pengujian autokorelasi menggunakan aplikasi program SPSS Versi 20 for windows dihasilkan output sebagai berikut : 
Hasil Output Spss Uji Autokorelasi Model Summary ${ }^{b}$

\begin{tabular}{|l|c|r|r|r|r|}
\hline Model & R & R Square & $\begin{array}{c}\text { Adjusted R } \\
\text { Square }\end{array}$ & $\begin{array}{c}\text { Std. Error of } \\
\text { the Estimate }\end{array}$ & $\begin{array}{c}\text { Durbin- } \\
\text { Watson }\end{array}$ \\
\hline 1 &, $644^{\mathrm{a}}$ &, 415 &, 402 & 2,54197 & 1,940 \\
\hline
\end{tabular}

a. Predictors: (Constant), Kecerdasan Emosional, Komitmen

Organisasi

b. Dependent Variable: Kinerja Karyawan

Dari output diatas dapat terlihat bahwa nilai Durbin Watson (DW) adalah sebesar 1,940, nilai ini akan kita bandingkan dengan nilai tabel signifikansi 5\%, jumlah sampel 97 ( $\mathrm{n}=97)$ dan jumlah variabel independent $2(\mathrm{~K}=2)$ maka didapatkan nilai dU sebesar 1,627, artinya nilai DW=1,940 lebih besar dari batas atas (dU) yakni sebesar 1,627 dan kurang dari (4dU) atau $4-1,711=2,289$. dari hasil tersebut dapat disimpulkan bahwa tidak terdapat autokorelasi atau Ha diterima dan Ho diterima.

\section{Koefisien Korelasi Parsial Kecerdasan Emosional $\left(\mathrm{X}_{1}\right)$ dengan Kinerja Pegawai (Y)}

Koefisien Korelasi Parsial adalah derajat atau tingkat hubungan antara dari variabel yang diukur dengan indeks. Korelasi dalam pengukurannya menggunakan perhitungan SPSS Versi 20. Koefisien parsial antara Kecerdasan Emosional $\left(\mathrm{X}_{1}\right)$ terhadap Kinerja Karyawan. Dengan asumsi bahwa Kecerdasan Emosional $\left(\mathrm{X}_{1}\right)$ dianggap konstan atau tetap, maka diperoleh sebagai berikut :

\section{Hasil Koefisien Korelasi Parsial}

Correlations

\begin{tabular}{|lll|r|r|}
\hline Control Variables & & $\begin{array}{c}\text { Komitmen } \\
\text { Organisasi }\end{array}$ & $\begin{array}{c}\text { Kinerja } \\
\text { Karyawan }\end{array}$ \\
\hline & Komitmen & Correlation & 1,000 &, 546 \\
Organisasi & Significance (2- & &, 000 \\
Kecerdasan & & Df &. & 94 \\
Emosional & & Correlation &, 546 & 1,000 \\
& Kinerja & Significance (2- &, 000 &. \\
& Karyawan & tailed) & 94 & 0 \\
\hline
\end{tabular}

Jika dilihat dari hasil perhitungan antara koefisien korelasi parsial variabel Kecerdasan Emosional terhadap produktivitas kerja sedangkan Komitmen Organisasi sebagai variabel kontrol maka diperoleh nilai korelasi sebesar 0,546 pada tabel interpretasi koefisien korelasi angka ini berada pada posisi rentang 0,40-0,599 dan mempunyai tingkat hubungan yang sedang, sedangkan nilai korelasi positif menurut sugiyono (2011:184) artinya jika Kecerdasan Emosional semakin meningkat maka kinerja karyawan akan semakin meningkat. 


\section{Koefisien Korelasi Parsial Komitmen Organisasi $\left(\mathbf{X}_{2}\right)$ terhadap Kinerja Karyawan} (Y)

Dengan asumsi bahwa Komitmen Organisasi $\left(\mathrm{X}_{2}\right)$ dianggap konstan atau tetap, maka diperoleh sebagai berikut :

\section{Hasil Koefisien Korelasi Parsial}

Correlations

\begin{tabular}{|c|c|c|c|c|}
\hline \multicolumn{3}{|c|}{ Control Variables } & $\begin{array}{l}\text { Kecerdasan } \\
\text { Emosional }\end{array}$ & $\begin{array}{c}\text { Kinerja } \\
\text { Karyawan }\end{array}$ \\
\hline $\begin{array}{l}\text { Komitmen } \\
\text { Organisasi }\end{array}$ & $\begin{array}{l}\text { Kecerdasan } \\
\text { Emosional } \\
\text { Kinerja } \\
\text { Karyawan }\end{array}$ & $\begin{array}{l}\text { Correlation } \\
\text { Significance (2-tailed) } \\
\text { df } \\
\text { Correlation } \\
\text { Significance (2-tailed) } \\
\text { df }\end{array}$ & $\begin{array}{r}1,000 \\
. \\
0 \\
, 362 \\
, 000 \\
94\end{array}$ & $\begin{array}{r}, 362 \\
, 000 \\
94 \\
1,000 \\
. \\
0\end{array}$ \\
\hline
\end{tabular}

Jika di lihat dari hasil perhitungan antara koefisien korelasi parsial variabel Komitmen Organisasi terhadap kinerja karyawan sedangkan Kecerdasan Emosional sebagai variabel kontrol maka diperoleh nilai korelasi sebesar 0,362 pada tabel interpretasi koefisien korelasi angka ini berada pada posisi rentang 0,20-0,399 dan mempunyai tingkat hubungan yang rendah, sedangkan nilai korelasi positif menurut sugiyono (2011:184) artinya jika komitmen organisasi semakin meningkat maka kinerja karyawan akan semakin meningkat.

\section{Analisis Regresi}

Analisis regresi adalah analisis yang di lakukan untuk mengukur besarnya pengaruh variabel bebas terhadap variabel terikat. Perhitungan analisis regresi menggunakan program SPSS. Versi 20 dan adapun model kelayakan regresi linear di dasarkan pada halhal sebagai berikut :

1. Predictor yang digunakan sebagai variabel bebas harus layak, kelayakan ini diketahui jika angka standar Error Of Estimate < Standar Deviation.

2. Data harus berdistribusi normal.

\section{Hasil Uji Regresi Linier Berganda}

\section{Coefficientsa}

\begin{tabular}{|c|c|c|c|c|c|}
\hline \multirow[t]{2}{*}{ Model } & \multicolumn{2}{|c|}{$\begin{array}{l}\text { Unstandardized } \\
\text { Coefficients }\end{array}$} & \multirow{2}{*}{\begin{tabular}{|c}
$\begin{array}{c}\text { Standardize } \\
\mathrm{d} \\
\text { Coefficient } \\
\mathrm{s}\end{array}$ \\
Beta
\end{tabular}} & \multirow[t]{2}{*}{$\mathrm{t}$} & \multirow[t]{2}{*}{ Sig. } \\
\hline & B & Std. Error & & & \\
\hline (Constant) & 8,457 & 2,609 & & 3,241 & ,002 \\
\hline $\begin{array}{l}\text { Kecerdasan } \\
\text { Emosional }\end{array}$ & ,276 & ,073 & ,303 & 3,761 & ,000 \\
\hline $\begin{array}{l}\text { Komitmen } \\
\text { Organisasi }\end{array}$ & ,508 & ,080 &, 509 & 6,316 & ,000 \\
\hline
\end{tabular}

a. Dependent Variable: Kinerja Karyawan 
Berdasarkan output SPSS untuk pengujian regresi berganda maka dari output tersebut dihasilkan persamaa regresi berganda adalah $\mathrm{Y}=8,457+\mathrm{X} 1=0,276+\mathrm{X} 2=0,508$ ini artinya bahwa jika kecerdasan emosional dan komitmen organisasi meningkat secara simultan maka secara otomatis juga akan meningkatkan kinerja karyawan di PT. Cogindo DayaBersama atau jika penerapan kecerdasan emosional pegawai diperusahaan itu baik dan komitmen organisasi diterapkan juga dengan baik maka kinerja karyawan PT. Cogindo Daya Bersama akan lebih baik.

\section{Analisis Koefisien Determinasi $\left(\mathbf{R}^{\mathbf{2}}\right)$}

Analisis ini digunakan untuk mengetahui besarnya kontribusi hubungan dua variabel independen terhadap variabel dependennya. Hasil output SPSS untuk koefisien determinasi adalah sebagai berikut:

\section{Hasil Koefisien Determinasi $\left(\mathbf{R}^{2}\right)$}

Model Summaryb

\begin{tabular}{|r|r|r|r|c|}
\hline Model & R & R Square & $\begin{array}{c}\text { Adjusted } \\
\mathrm{R} \\
\text { Square }\end{array}$ & $\begin{array}{c}\text { Std. Error of the } \\
\text { Estimate }\end{array}$ \\
\hline 1 &, $644^{\mathrm{a}}$ & 0,415 & 0,402 & 2,54197 \\
\hline
\end{tabular}

a. Predictors: (Constant), Komitmen Organisasi, Kecerdasan Emosional

b. Dependent Variable: Kinerja Karyawan

Berdasarkan tabel diatas diketahui nila $\mathrm{R}^{2}$ sebesar $41 \%$ adalah menunjukan besarnya kontribusi hubungan kecerdasan emosional dan komitmen organisasi secara simultan dengan kinerja karyawan pada PT. Cogindo DayaBersama sedangkan sisanya sebesar 59\% di kontribusi oleh faktor lain yang tidak diamati dalam penelitian ini faktor lain itu misalnya, motifasi, kepemimpinan dll.

\section{Uji parsial (Uji-t)}

\section{Hasil Uji-t}

Coefficients $^{\mathrm{a}}$

\begin{tabular}{|rl|r|r|r|r|r|}
\hline \multirow{2}{*}{ Model } & \multicolumn{2}{|c|}{$\begin{array}{c}\text { Unstandardized } \\
\text { Coefficients }\end{array}$} & $\begin{array}{c}\text { Standardized } \\
\text { Coefficients }\end{array}$ & \multirow{2}{*}{$\mathrm{t}$} & \multirow{2}{*}{ Sig. } \\
\cline { 3 - 5 } & \multicolumn{1}{|c|}{ B } & $\begin{array}{c}\text { Std. } \\
\text { Error }\end{array}$ & Beta & & \\
\hline \multirow{2}{*}{1} & $\begin{array}{l}\text { (Constant) } \\
\text { Kecerdasan }\end{array}$ & 8,457 & 2,609 & & 3,241 &, 002 \\
& Emosional &, 276 &, 073 &, 303 & 3,761 &, 000 \\
\hline
\end{tabular}

a. Dependent Variable: Kinerja Karyawan

1. Uji-t pertama

Dengan menggunakan output SPSS analisis regresi sederhana antara kecerdasan emosional terhadap kinerja karyawan maka diketahui t-hitung $=3,761$ nilai tersebut dibandingkan 
dengan nilai $\mathrm{t}$-tabel dengan derajat kebebasan $=97-2=95$ maka didapat $\mathrm{t}$-tabel sebesar 1,661 sehingga $t$-hitung terlihat lebih besar dari pada $t$-tabel sesuai dengan ketentuan uji hipotesis terbukti bahwa terdapat pengaruh yang signifikan kecerdasan emosional terhadap kinerja karyawan PT. Cogindo DayaBersama.

\section{Hasil Uji-t}

Coefficients $^{\mathrm{a}}$

\begin{tabular}{|c|c|c|c|c|c|}
\hline \multirow[t]{2}{*}{ Model } & \multicolumn{2}{|c|}{$\begin{array}{l}\text { Unstandardized } \\
\text { Coefficients }\end{array}$} & $\begin{array}{c}\text { Standardize } \\
\mathrm{d} \\
\text { Coefficients }\end{array}$ & \multirow[t]{2}{*}{$\mathrm{t}$} & \multirow[t]{2}{*}{ Sig. } \\
\hline & B & $\begin{array}{l}\text { Std. } \\
\text { Error }\end{array}$ & Beta & & \\
\hline (Constant) & 8,457 & 2,609 & & 3,241 & ,002 \\
\hline $\begin{array}{l}\text { Komitmen } \\
\text { Organisasi }\end{array}$ & ,508 & ,080 & ,509 & 6,316 & ,000 \\
\hline
\end{tabular}

a. Dependent Variable: Kinerja Karyawan

\section{Uji-t kedua}

Dengan menggunakan output SPSS analisis regresi sederhana antara komitmen organisasi terhadap kinerja karyawan maka diketahui $\mathrm{t}$-hitung $=6,316$ nilai tersebut dibandingkan dengan nilai $\mathrm{t}$-tabel dengan derajat kebebasan $=97-2=95$ maka didapat $\mathrm{t}-$ tabel sebesar 1,661 sehingga t-hitung terlihat lebih besar dari pada t-tabel sesuai dengan ketentuan uji hipotesis terbukti bahwa terdapat pengaruh yang signifikan kecerdasan emosional terhadap kinerja karyawan PT. Cogindo DayaBersama.

\section{Uji Simultan (Uji-f)}

Hasil Uji F

ANOVA ${ }^{\mathrm{a}}$

\begin{tabular}{|l|r|r|r|c|c|}
\hline Model & Sum of Squares & df & $\begin{array}{c}\text { Mean } \\
\text { Square }\end{array}$ & F & Sig. \\
\hline Regression & 430,092 & 2 & 215,046 & 33,280 &, $000^{\mathrm{b}}$ \\
1 Residual & 607,393 & 94 & 6,462 & & \\
\multicolumn{1}{|l|}{ Total } & 1037,485 & 96 & & & \\
\hline
\end{tabular}

a. Dependent Variable: Kinerja Karyawan

b. Predictors: (Constant), Komitmen Organisasi, Kecerdasan Emosional

Berdasarkan tabel hasil perhitungan Statistik uji $\mathrm{F}$ diatas, menunjukkan nilai $\mathrm{F}_{\text {-hitung }}>\mathrm{F}$ tabel yaitu 33,280 > 3,94 maka dapat disimpulkan bahwa Ho ditolak dan $\mathrm{H}_{3}$ diterima, Artinya Kecerdasan Emosional $\left(\mathrm{X}_{1}\right)$ dan Komitmen Organisasi $\left(\mathrm{X}_{2}\right)$ secara bersama-sama berpengaruh positif dan signifikan terhadap Kinerja Karyawan (Y), dengan demikian nilai Kecerdasan Emosional dan Komitmen Organisasi secara bersama-sama semakin meningkat, maka kinerja pegawai akan semakin meningkat. 


\section{KESIMPULAN DAN SARAN}

\section{Kesimpulan}

Berdasarkan hasil analisis dan pembahasan, tentang Pengaruh Kecerdasan Emosional dan Komitmen Organisasi Terhadap Kinerja Karyawan PT. Cogindo DayaBersama Unit Suralaya, penulis menarik kesimpulan sebagai berikut :

1. Koefisien korelasi variable kecerdasan emosional terhadap produktifitas kerja memiliki nilai korelasi sebesar 0,546 pada tabel koefisien korelasi angka ini berada pada posisirentang 0,40-0,599 dan mempunya tingkat hubungan yang sedang, artinya kecerdasan emosional semakin meningkat maka kinerja karyawan akan semakin meningkat.

2. Terdapat pengaruh antara kecerdasan emosional terhadap kinerja karyawan pada PT. Cogindo DayaBersama unit suralaya. Didapat hasil $t_{\text {hitung }}>t_{\text {tabel }}=(3,761>1,661)$, dengan tingkat signifikansi $<0,05$ maka $\mathrm{H}_{\mathrm{o}}$ ditolak $\mathrm{H}_{1}$ diterima. Artinya terdapat pengaruh positif dan signifikan antara kecerdasan emoisonal terhadap kinerja pegawai PT. Cogindo DayaBersama unit suralaya, sedangkan nilai regresi sebesar 0,276 mempunyai tingkat hubungan yang kuat artinya nilai kecerdasan emosional meningkat maka kerja karyawan akan semakin meningkat

3. Terdapat pengaruh antara komitmen organisasi terhadap kinerja karyawan pada PT. Cogindo DayaBersama unit suralaya. Didapat hasil $t_{\text {hitung }}>t_{\text {tabel }}=(6,316>1,661)$, dengan tingkat signifikansi $<0,05$ maka $\mathrm{H}_{\mathrm{o}}$ ditolak $\mathrm{H}_{1}$ diterima. Artinya terdapat pengaruh positif dan signifikan antara kecerdasan emoisonal terhadap kinerja pegawai PT. Cogindo DayaBersama unit suralaya, sedangkan nilai regresi sebesar 0,508 mempunyai tingkat hubungan yang kuat artinya nilai kecerdasan emosional meningkat maka kerja karyawan akan semakin meningkat.

4. Terdapat pengaruh antara kecerdasan emosional dan komitmen organisasi secara bersama-sama terhadap kinerja karyawan pada PT Cogindo DayaBersama, dengan keputusan $F_{\text {hitung }}>F_{\text {tabel }}=(33,280>3,94)$, dengan demikian $\mathrm{H}_{\mathrm{O}}$ ditolak dan $\mathrm{H}_{\mathrm{a}}$ diterima artinya terdapat pengaruh positif dan signifikan antara kecerdasan emosional dan komitmen organisasi secara bersama-sama terhadap kinerja karyawan pada PT Cogindo DayaBersama.

\section{Saran}

Berdasarkan hasil pembahasan dan kesimpulan diatas, maka penulis memberikan saran-saran sebagai berikut:

a. Untuk Instansi

Kecerdasan emosional dan komitmen organisasi secara umum sudah memberikan kontribusi yang cukup tinggi terhadap kualitas kinerja karyawan PT. Cogindo Daya Bersama, tetapi masih ada beberapa hal yang masih perlu ditingkatkan lagi terutama pada :

1. Kemampuan karyawan untuk mengenali perasaan rekan kerja saat melakukan pekerjaan dan bersosialisasi (84) 
2. Perasaan nyaman karyawan terhadap perusahaan sehinggga sulit untuk bertahan dalam organisasi (78)

3. Rasa tanggung jawab karyawan terhadap pekerjaan yang dikerjakan yang berdampak pada menurunnya hasil kerja (75)

4. Kemampuan untuk menjaga kualita kerja (83)

5. Kesadaran kerja karyawan masih kurang sehingga tingkat kesalahan kerja masih tinggi (98)

Oleh karena itu harus mampu menjaga bahkan meningkatkan kualiatas kecerdasan emosional dan komitmen organisasi guna peningkatan kinerja karyawan yang lebih baik.

b. Untuk Pihak Lain

1. Bagi pihak lain yang ingin melakukan penelitian dengan variabel-variabel yang sama, yaitu pengaruh kecerdasan emosional dan komitmen organisasi terhadap kinerja karyawan pada PT.Cogindo Daya Bersama unit Suralaya, diharapkan mampu melakukan penelitian dengan lebih baik, sehingga penelitian ini dapat berkembang dan mendapatkan hasil yang lebih akurat. Hal ini juga dapat dijadikan pembanding sekaligus melengkapi penelitian ini.

2. Bagi pihak lain yang melakukan penelitian dilakukan lokasi yang sama diharapkan mengganti variabel yang telah diteliti tersebut karena setiap instansi atau perusahaan mempunyai banyak permasalahan yang dapat dijadikan variabel dalam penelitian. Dengan demikian penelitian yang akan datang semakin banyak menemukan permasalahan yang ada diperusahaan, dengan demikian penelitian yang akan datang diharapkan mampu memberikan solusi dan pemecahan masalah demi memajukan perusahaan dimasa yang akan datang.

\section{DAFTAR PUSTAKA}

Goleman. (2009). Emotional Intelligence (terjemahan). Jakarta : PT Gramedia Pustaka Utama.

Makmun Mubayidh. (2006). Kecerdasan dan Kesehatan Emosional Anak (Muhamad Muchson Anasy. S.HI. Terjemahan). Jakarta: PT. Al Kautsar.Agustian.

Robbins dan Judge. (2008), perilaku Organisasi, buku 1 dan 2. Jakarta : Salemba Empat.

Sopiah, (2008) Perilaku Organisasi, Andi : Yogyakarta.

Sugiyono. (2005) Metode Penelitian Bisnis. Bandung: CV Alfabeta. (2010). Metode Penelitian Kuantitatif Kualitatif dan R\&D. Bandung: CV 